\title{
Prognostic Prediction of Novel Risk Scores (AML- DRG and AML-HCT-CR) in Acute Myeloid Leukemia Patients with Allogeneic Hematopoietic Stem Cell Transplantation
}

\section{Weijie Cao}

First Affiliated Hospital of Zhengzhou University

\section{Xiaoning Li}

First Affiliated Hospital of Zhengzhou University

\section{Ran Zhang}

First Affiliated Hospital of Zhengzhou University

Zhilei Bian

First Affiliated Hospital of Zhengzhou University

\section{Suping Zhang}

First Affiliated Hospital of Zhengzhou University

Li Li

First Affiliated Hospital of Zhengzhou University

Haizhou Xing

First Affiliated Hospital of Zhengzhou University

Changfeng Liu

First Affiliated Hospital of Zhengzhou University

\section{Xinsheng Xie}

First Affiliated Hospital of Zhengzhou University

\section{Zhongxing Jiang}

First Affiliated Hospital of Zhengzhou University

Jifeng Yu ( $\nabla$ yujifengzzu@163.com )

First Affiliated Hospital of Zhengzhou University

\section{Dingming Wan}

First Affiliated Hospital of Zhengzhou University

\section{Research Article}

Keywords: Acute myeloid leukemia, allogeneic hematopoietic stem cell transplantation, risk score models, prognostic prediction

Posted Date: November 18th, 2021 
DOI: https://doi.org/10.21203/rs.3.rs-1045274/v1

License: (c) (1) This work is licensed under a Creative Commons Attribution 4.0 International License. Read Full License 


\section{Abstract \\ Purpose}

We aimed to validate and prove the novel risk score models of acute myeloid leukemia (AML)-specific disease risk group (AML-DRG) and AML-Hematopoietic Cell Transplant-composite risk (AML-HCT-CR) in patients with acute myeloid leukemia (AML) after allogeneic hematopoietic stem cell transplantation (AHCT).

\section{Methods}

One hundred twenty-three AML (non-APL) patients underwent AHCT was enrolled in this study. Patients were stratified into 3 AML-DRG and 4 AML-HCT-CR risk groups. Of the 123 patients, 57 (46.3\%) were females, and the median age was 31 years (range 12 to 62 years). All patients received myeloablative conditioning. Median follow-up was 46 months (range 1 to 94 months). AML-DRG and AML-HCT-CR score models were applied with the overall survival (OS) and progression-free survival (PFS) analysis after the clinical followup.

\section{Results}

For the AML-DRG model, the 3-year OS in the low, intermediate and high-risk groups were $65.4 \%, 34.9 \%$ and $8.3 \%$, respectively $(p<0.001)$. The corresponding 3 -year PFS were $64.0 \%, 34.9 \%$ and $8.3 \%(p<0.001)$. The OS predictive accuracy measured by C-index was 0.680 . In the AML-HCT-CR model, the 3-year OS in the low, intermediate, high and very high-risk groups were $65.4 \%, 52.0 \%, 11.1 \%$ and $8.3 \%$, respectively $(p<0.001)$. The corresponding 3-year PFS were $64.0 \%, 52.0 \%, 11.1 \%$ and $8.3 \%(p<0.001)$. The OS predictive accuracy measured by C-index was 0.705 . The AML-DRG and AML-HCT-CR models significantly predicted cumulative incidence of relapse $(p=0.002 ; p=0.005)$. But both scores were not associated with NRM $(p=0.314 ; p=0.095)$. Univariate analysis showed that the AML-DRG model could better stratify AML patients into different risk groups compared to the AML-HCT-CR model. Multivariate analysis confirmed that prognostic impact of AML-DRG and AML-HCT-CR models on post-transplant OS was independent to age, sex, conditioning type, transplant modality, and stem cell source $(p<0.001 ; p<0.001)$.

\section{Conclusions}

The AML-DRG and AML-HCT-CR models can be used to effectively predict post-transplant survival in patients with AML receiving AHCT in our center. Compared to AML-HCT-CR score, the AML-DRG score allows better stratification and improved survival prediction of AML patients post-transplant.

\section{Introduction}


Acute myeloid leukemia (AML) is a clonal malignancy characterized by genetic heterogeneity due to recurrent gene mutations. Long term overall survival has stagnated in the past few decades. Even with an array of new gene mutation-targeted agents available for AML treatment [1], the complete cure of leukemia still faces great challenges. Allogeneic hematopoietic stem cell transplantation (AHCT) is a curative treatment for AML patients [2, 3]. Disease relapse and transplant-related mortality (TRM) are important for long-term survival of AML patients, especially the disease relapse [4, 5]. How to identify the high-risk patients and prevent post-AHCT relapse on the basis of controlling the toxicities of conditioning regimen was important to improve the outcomes of AML patients [6,7]. Survival of patients after AHCT is largely dependent on disease- and patient-related factors [8-12]. Pre-transplant risk and survival assessments are the keys to optimize the results of transplant.

Several prognostic models have been developed in recent years. The disease risk index (DRI) [13, 14], representing disease-related factors, can predict overall survival (OS) but can't integrate patient's comorbidities and overall conditions. The hematopoietic cell transplantation-specific comorbidity index (HCT-Cl) is also predictive of outcome but only includes comorbidities $[15,16]$. The disease risk comorbidity index (DRCl) and haplo-DRCl, integrating the DRI and $\mathrm{HCT}-\mathrm{Cl}$, can effectively predict outcomes after AHCT [17]. Although previous studies have proved that minimal residual disease (MRD) is an independent predictor of survival in patients with AML [18-20], MRD is excluded from most models. Therefore, two comprehensive new prognostic scores, AML-specific disease risk group (AML-DRG) and AML-Hematopoietic Cell Transplant-Composite Risk (AML-HCT-CR), have been shown to be predictive of OS and PFS in patients with AML received AHCT [21]. However, there are no published reports of the AML-DRG and AML-HCT-CR models in China. In this retrospective study, we aimed to verify the clinical effectiveness and generalizability of the AML-DRG and AML-HCT-CR models in a cohort of patients with AML receiving AHCT.

\section{Materials And Methods}

\section{Data source}

A total of 123 adult patients diagnosed with non-M3 acute myeloid leukemia who underwent the first AHCT from January 1, 2013 to December 30, 2018 in the First Affiliated Hospital of Zhengzhou University were enrolled in this study. Secondary AML was defined as AML developed after treatment with systemic chemotherapy and/or radiation therapy. All enrolled subjects in this study provided written informed consent. The study was conducted in accordance with the Declaration of Helsinki. All patients were followed up through our outpatient clinic, medical records in hospital, or by telephone cells. The follow-up endpoint was December 30, 2020.

Rating scales

AML-DRG score assignment: 1 for secondary AML, 1 for adverse European Leukemia 2017 genetic risk (ELN2017 genetic risk), 2 for CR with MRD positive or unknown MRD status, 4 for active disease [21]. The AML-HCT-CR score assignment: AML-DRG score with the addition of 1 score for age $\geq 60$ and 1 score for $\mathrm{HCT}-\mathrm{Cl} \geq 3$ [21]. DRI was applied as described by Armand et al [13]. HCT-Cl and HCT-Cl/Age were applied as 
published by Sorror et al [15, 16]. ELN2017 genetic risk group was applied as described by Döhner, et al [22]. MRD was assessed pre-HSCT by flow cytometry. MRD $<0.1 \%$ was judged to be negative [23].

Transplant protocol

All patients received myeloablative conditioning. The major conditioning regimen for the identical sibling donor (ISD) group as follows: hydroxyurea (40mg/kg/12h, day -10), cytarabine (1 1.5g/m-2/d, day -9 ), busulfan $(0.8 \mathrm{~g} / \mathrm{kg} / 6 \mathrm{~h}$, days $-8 \sim-6)$, cyclophosphamide $(1.8 \mathrm{~g} / \mathrm{m}-2 / \mathrm{d}$, days -5 and -4$)$. For HLA-haploidentical and HLA-matched unrelated donor transplants, the major conditioning regimen as follows: cytarabine (4g/ $\mathrm{m}-2 / \mathrm{d}$, days -10 and -9$)$, busulfan $(0.8 \mathrm{~g} / \mathrm{kg} / 6 \mathrm{~h}$, days -8 to -6$)$, cyclophosphamide $(1.8 \mathrm{~g} / \mathrm{m}-2 / \mathrm{d}$, days -5 and $-4)$, anti-thymocyte globulin (ATG) $(2.5 \mathrm{mg} / \mathrm{kg} / \mathrm{d}$, days -5 to -2$)$. Four patients received total body irradiation (TBI)-based regimen: cyclophosphamide $(60 \mathrm{mg} / \mathrm{kg} / \mathrm{d}$, day -6 and -5$)$, total body irradiation (12 to $14 \mathrm{~Gy}$, day $-3 \sim-1)$. The GVHD prevention scheme used cyclosporine combined with mycophenolate mofetil and methotrexate.

\section{Outcomes}

The primary endpoint was overall survival (OS) at 3 years after transplantation. The secondary endpoints were progression-free survival (PFS) at 3 years, non-relapse mortality (NRM) at 3 years, and cumulative incidence of relapse at 3 years. OS was defined as time from transplantation until death from any cause. PFS was defined as time from randomization to disease progression. Non-relapse mortality was defined as death from any cause not subsequent to relapse. Relapse was defined as either reappearance of leukemic blasts in the peripheral blood or at least $5 \%$ blasts in the bone marrow aspirate or biopsy specimen not attributable to any other cause, or reappearance or new appearance of extramedullary leukemia. Acute GVHD and chronic GVHD were diagnosed and graded according to the standard international criteria [24, 25].

Statistical analysis

OS, PFS were estimated using the Kaplan-Meier method and compared using the Log-rank test. Cumulative incidences of relapse, non-relapse mortality, and GVHD were calculated by accounting for competing risks. Competing risks for GVHD included death without GVHD and relapse. Relapse was a competing risk for nonrelapse mortality, and non-relapse mortality was a competing risk for relapse. The comparison of the cumulative incidence in the presence of a competing risk was done using the Fine and Gray model. The impact of the AML-DRG and AML-HCT-CR models on survival outcomes were determined using univariable and multivariable Cox proportional hazards regression models. The discriminative ability of the models was assessed by Harrell's C-statistics. $p<0.05$ was considered significant. SPSS version 23.0 and R version 3.6.2 were used for data analysis.

\section{Results}

Patient characteristics 
Among the 123 AML patients analyzed, $46.3 \%(n=57)$ were females. Median age was 31 years (range 12 to 62 years), one patient was more than 60 years old ( $0.81 \%$ ). Median follow-up was 46 months (range 1 to 94 months). According to the AML-DRG model, 68,43 and 12 patients were in low-, intermediate- and high-risk group, respectively. According to the AML-HCT-CR model, 68, 25, 18 and 12 patients were in low-, intermediate-, high- and very high-risk group, respectively. The basic clinical data of the patients were shown in Table 1.

GVHD

For the entire cohort, the cumulative incidence of grade II to IV acute GVHD at day 100 was $18.7 \%(95 \% \mathrm{Cl}$ 15.4-22), the cumulative incidence of all-grade chronic GVHD at 2 years was $25.4 \%$ (95\% $\mathrm{Cl} 21.9-28.9)$. The cumulative 100-day incidence of grade II to IV acute GVHD for the low-, intermediate- and high-risk AML-DRG groups was 19.1\% (95\% Cl 16.6-21.7), 18.6\% (95\% Cl 11.3-25.9) and 16.7\% (95\% Cl 0-36.0), differences are not statistically significant $(P=0.980)$. The incidence for all-grade chronic GVHD at 2 years was $31.3 \%(95 \%$ $\mathrm{Cl} 25.6-37.0), 20.9 \%(95 \% \mathrm{Cl} 13.4-28.4)$ and $8.3 \%$ (95\% Cl 0-25.8), respectively ( $\mathrm{p}=0.211)$ (Table 2$)$.

For the AML-HCT-CR model, the cumulative 100-day incidence of grade II to IV acute GVHD for the low-, intermediate-, high- and very high-risk groups was $19.1 \%$ (95\% Cl 13.9-24.3), 12.0\% (95\% Cl 1.9-22.1), $27.8 \%$ (95\% Cl 12.6-43.0) and 16.7\% (95\% Cl 0.0-36.2), respectively $(\mathrm{p}=0.610)$. The incidence for all-grade chronic GVHD at 2 years was $31.3 \%(95 \% \mathrm{Cl} 25.6-37.0), 28.0 \%$ (95\% Cl 16.1-39.9), 11.1\% (95\% Cl 0-24.1) and 8.3\% (95\% Cl 0-26.5), respectively ( $\mathrm{p}=0.252)$ (Table 2$)$.

Relapse and NRM

For the entire cohort, the 3-year cumulative incidences of relapse and NRM were 23.0\% (95\% Cl 19.6-26.4) and $28.6 \%$ (95\% $\mathrm{Cl} 25.0-32.2)$, respectively. Reasons for relapse were hematological in 20 patients, extramedullary in 3 patients, and hematological plus extramedullary in 5 patients. Reasons for NRM were infection in 22 patients, acute GVHD in 11 patients, and hemorrhage in 5 patients.

The 3-year cumulative incidence of relapse for the low-, intermediate- and high-risk AML-DRG groups was 13.6\% (95\% Cl 8.7-18.5), 30.2\% (95\% Cl 22.3-38.2) and 50.0\% (95\% Cl 27.6-72.4), respectively ( $\mathrm{p}=0.002)$ (Figure 1B), with the corresponding 3-year NRM was 22.3\% (95\% Cl 17.0-27.7), 34.9\% (95\% Cl 26.8-43.0) and 41.7\% (95\% Cl 19.0-64.4), differences are not statistically ( $p=0.314)$ (Figure 1C). The 3-year cumulative incidence of relapse for the low-, intermediate-, high- and very high-risk AML-HCT-CR groups was $13.6 \%$ (95\% $\mathrm{Cl}$ 8.7-18.5), 24.0\% (95\% Cl 12.4-35.6), 44.4\% (95\% Cl 28.3-60.6) and 41.7\% (95\% Cl 19.7-63.6), respectively $(\mathrm{p}=0.005)$ (Figure 2B), with the corresponding 3-year NRM was $22.3 \%$ (95\% Cl 17.0-27.7), $24.0 \%(95 \% \mathrm{Cl}$ 12.4-35.6), 44.4\% (95\% Cl 28.2-60.7) and 50.0\% (95\% Cl 27.3-72.7), differences are not statistically significant ( $\mathrm{p}=0.095)$ (Figure 2C, Table 2).

\section{OS and PFS}

The 3-year OS and PFS of the entire cohort were 49.1\% (95\% Cl 41.0-58.9) and 48.4\% (95\% Cl 40.3-58.1). Patients in low-, intermediate- and high-risk AML-DRG groups had median OS of 33.5 (1 94), 10 (1 60) and 4 (1 69) months, respectively ( $p<0.001)$, with the corresponding 3-year OS of 65.4\% (95\% Cl 54.9-78.0), 
$34.9 \%(95 \% \mathrm{Cl} 23.2-52.5)$ and $8.3 \%(95 \% \mathrm{Cl} 1.3-54.4)$, respectively $(\mathrm{p}<0.001)$. The 3-year PFS were $64.0 \%$ (95\% $\mathrm{Cl} 53.5-76.7), 34.9 \%(95 \% \mathrm{Cl} 23.2-52.5)$ and $8.3 \%$ (95\% Cl 1.3-54.4), respectively $(\mathrm{p}<0.001)$ (Figure $1 \mathrm{~A})$.

The median OS for the low-, intermediate-, high- and very high-risk AML-HCT-CR groups were 33.5 (1 94), 28 (2 60), 6.5 (1 43) and 3.5 (1 69) months, respectively ( $p<0.001)$, with the corresponding 3-year OS of 65.4\% (95\% Cl 54.9-78.0), 52.0\% (95\% Cl 35.7-75.8), 11.1\% (95\% Cl 3.0-41.0) and 8.3\% (95\% Cl 1.3-54.4), respectively ( $\mathrm{p}<0.001)$ (Figure 2A). The 3-year PFS were 64.0\% (95\% Cl 53.5-76.7), 52.0\% (95\% Cl 35.7-75.8), $11.1 \%(95 \% \mathrm{Cl} 3.0-41.0)$ and $8.3 \%(95 \% \mathrm{Cl} 1.3-54.4)$, respectively $(\mathrm{p}<0.001)$ (Table 2$)$.

In univariable analysis for OS, patients with intermediate and high-risk AML-DRG groups had a significantly increased risk of death with hazard ratio $(\mathrm{HR})$ of 2.29 (95\% Cl 1.3-3.9; $\mathrm{p}=0.003)$ and $5.14(95 \% \mathrm{Cl} 2.5-10.6$; $\mathrm{p}<0.001)$, respectively when compared with the low-risk group. Also, the risk of death was higher in high-risk group compared with the intermediate-risk group (HR 2.26, 95\% Cl 1.1-4.6; $p=0.023$ ), confirming the ability of the AML-DRG model in post-transplant survival prediction. For AML-HCT-CR groups, patients with high (HR $4.43,95 \% \mathrm{Cl} 2.3-8.5 ; \mathrm{p}<0.001$ ) and very high-risk groups (HR 5.82, 95\% $\mathrm{Cl} 2.8-12.0 ; \mathrm{p}<0.001$ ) had significantly increased risk of death than low-risk group, while there was no difference between low and intermediate-risk (HR 1.37, 95\% Cl 0.7-2.7; $\mathrm{p}=0.365)$ and between high and very high group (HR 1.47,95\% $\mathrm{Cl} 0.7-3.2 ; \mathrm{p}=0.329)$. Similar results were found in a univariable analysis for PFS as summarized in Table 3.

Multivariate analysis

Multivariable analysis confirmed that the HCT-CR and AML-HCT-CR models could be used to predict the OS of patients in different risk groups after adjusted for other variables including age, sex, conditioning type, transplant modality, and stem cell source. See Table 4 for details.

Comparison of prognostic stratification:

The C-indexes of the AML-DRG, AML-HCT-CR, DRI, ELN2017 genetic risk, and HCT-Cl/Age model were 0.680 (95\% Cl 0.586-0.774), 0.705 (95\% Cl 0.613-0.797), 0.605 (95\% Cl 0.506-0.705), 0.519 (95\% Cl 0.416-0.621) and 0.601 (95\% $\mathrm{Cl} 0.501-0.700)$, respectively. Compared with the DRI model and the HCT-Cl/Age, the AMLDRG and AML-HCT-CR models had significantly better discrimination ability on OS prediction with C-index. The risk assessment ability of AML-DRG and AML-HCT-CR may be better than that of ELN2017 genetic risk, DRI and $\mathrm{HCT}-\mathrm{Cl} /$ Age models.

\section{Discussion}

Risk stratification is essential to predict the prognosis of patients with AML receiving AHCT. Recently, the AML-DRG and AML-HCT-CR models, which combines DRI, HCT-Cl, ELN2017 risk classification, MRD and other important prognostic factors, was published and has demonstrated a significant impact in terms of OS and PFS [21]. In this study, we examined the effect of the AML-DRG and AML-HCT-CR models on clinical outcomes of AHCT. The results demonstrated that both AML-DRG and AML-HCT-CR models could significantly predict the OS, PFS and relapse. While the NRM and GVHD did not reach statistical significance. 
In our monocenter retrospective study including 123 patients with $A M L$, we confirmed that the AML-DRG and AML-HCT-CR models have a prognostic prediction on OS and PFS (all $p<0.001$ ). This is consistent with the reference publication. Kongtim et al [21] reported that the OS at 5 years for low-, intermediate- and high-risk AML-DRG risk groups were $62.8 \%, 33.1 \%$ and $12.6 \%$, respectively, and 5-year PFS were $60.4 \%, 31.1 \%$, and $7.9 \%$, respectively. The OS at 5 years for low-, intermediate-, high- and very high-risk AML-HCT-CR risk groups were $71.1 \%, 53.6 \%, 37.4 \%$, and $12.7 \%$, respectively, the corresponding PFS at 5 years were $67.4 \%, 51.7 \%$, $36.2 \%$, and $9.6 \%$, respectively. We also performed pairwise comparisons in survival analysis among different groups. The results showed that for AML-DRG, all pairwise comparisons were statistically significant. However, unlike the reference publication, we did not find the difference of OS between AML-HCT-CR low-risk and intermediate-risk group $(65.4 \%$ vs $52.0 \%$, $p=0.365)$, high-risk and very high-risk group $(11.1 \%$ vs $8.3 \%$, $\mathrm{p}=0.329)$. Fist, this is a single-centre study, the sample of high- and very high-risk AML-HCT-CR patients was relatively small. Second, in our study, the conditioning regimens included busulfan (Bu)- and total body irradiation (TBI)-based regimens in patients, while the reference publication included busulfan (Bu)- and Melphalan-based regimens. Third, unlike the reference publication, only one patient in our sample was older than 60 years. Perhaps these reasons caused our results to be different from the reference publication. Therefore, a multi-center clinical trial is required to confirm the findings from the reference publication. The multivariable analyses have shown that prognostic prediction of the AML-DRG and AML-HCT-CR models on post-transplant survival was independent to age, sex, conditioning type, transplant modality, and stem cell source $(p<0.001 ; p<0.001)$. This means that the model can be applied in patients transplanted using both HLA-matched and unmatched donors.

Since the AML-DRG and AML-HCT-CR models have been developed and validated their utility in mortality prediction, we further identified the specific cause of mortality. Our study found that the AML-DRG and AMLHCT-CR models were associated with the 3-year OS, mainly due to relapse. The AML-DRG model categorized patients into 3 distinct relapse risk groups, with 3-year cumulative incidence of relapse ranging between $13.6 \%$ for the low-risk group to $50.0 \%$ for the high-risk group. Similar results were found for the AML-HCT-CR model (13.6\% for the low-risk group and $41.7 \%$ for the very high-risk group). The results suggest that for the patients in the intermediate and high-risk groups of AML-DRG and AML-HCT-CR models, MRD and other related indexes should be closely monitored after transplantation, and maintenance treatment or preemptive treatment should be given, so as to reduce the risk of recurrence and improve the efficacy of the transplantation. Patients in the very high-risk AML-HCT-CR group had higher recurrence and NRM rates, especially high NRM rates (41.7\% for relapse rate and $50.0 \%$ for NRM rate). These patients usually had advanced-stage disease and/or high comorbidities burden before AHCT, which suggested that they had a higher risk of disease relapse and may be vulnerable to drug toxicities and transplant complications. A lower intensity conditioning regimen may help to prevent the transplant-related toxicity and mortality. However, this may lead to high relapse rates after AHCT, particularly for those with relapse/refractory leukemia [6, 7]. Therefore, how to prevent relapse after AHCT on the basis of controlling the toxicity of the conditioning regimen is important to improve the clinical outcome of patients with very high-risk AML-HCT-CR group.

Our study found that the AML-DRG and AML-HCT-CR models had a significantly better discrimination ability on OS prediction with Harrell C-index of 0.680 and 0.705 , respectively, when compared with the DRI model (C-index 0.593), HCT-Cl/Age (C-index 0.580) and ELN2017 risk classification (C-index 0.519). This was 
partially in accordance with the reference study in which the AML-DRG and AML-HCT-CR models significantly better predicted risk of death after transplant with C-indices of 0.672 and 0.715 , respectively [21]. It demonstrated that AML-DRG and AML-HCT-CR models provide better tools for risk stratification of patients.

In addition, both AML-DRG and AML-HCT-CR models were not prognostic for NRM and GVHD, those data are also very important for HSCT choice. Further incorporation of NRM- and GVHD- related specificity indicators may help to achieve a more comprehensive scoring system. Although HCT-Cl had been considered be prognostic of NRM and GVHD [16, 26, 27], we did not find AML-HCT-CR be prognostic for NRM and GVHD. A possible explanation for our results is that combining AML-DRG and HCT-Cl probably weakens the weight of $\mathrm{HCT}-\mathrm{Cl}$ in NRM and GVHD prognostication.

\section{Conclusion}

In conclusion, our data confirm results similar to the reference publication and provide useful information on OS, PFS, relapse, and NRM prediction. The AML-DRG and AML-HCT-CR models allow better stratification and improved survival estimates of AML patients post-transplant. Considering the absence of prognosis for NRM and GVHD, we recommend using the AML-DRG and HCT-Cl separately to obtain more accurate and relevant information to guide transplant choice.

\section{Abbreviations}

aGVHD囚acute GVHD

AHCT囚allogeneic hematopoietic stem cell transplantation

AML囚acute myeloid leukemia

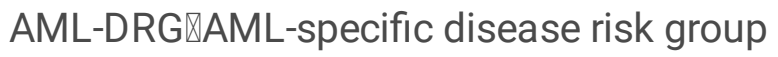

AML-HCT-CR囚AML-Hematopoietic Cell Transplant-composite risk

ATG \anti-thymocyte globulin

BMSC『bone marrow stem cell

Bu囚busulfan

cGVHD『chronic GVHD

Cl『confidence interval

CR囚complete remission

DRCI区disease risk comorbidity index 
DRI囚disease risk index

ELN2017 genetic risk囚European Leukemia Net 2017 genetic risk

HCT-CI区hematopoietic cell transplantation-specific comorbidity index

HR囚hazard ratio

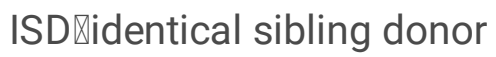

MRD囚minimal residual disease

NRM $₫$ non-relapse mortality

OS\overall survival

PBSC『peripheral blood stem cell

PFS®progression-free survival

TBIØtotal body irradiation

TRM \transplant-related mortality

\section{Declarations}

\section{Availability of data and materials}

Data and material will be available upon corresponding author approval. All data sets generated/analysed for this study are included in the manuscript and the additional files.

\section{Acknowledgments}

This work was supported by the Project of Henan Provincial Education Department, China (20A320062, recipient JY), Project of Science and Technology Department of Henan Province, China (LHGJ20190039, recipient JY), Project of Science and Technology Department of Henan Province, China (SBGJ20202076, recipient JY), Talent Research Fund of the First Affiliated Hospital of Zhengzhou University, Zhengzhou, China (recipient JY), and Key scientific research projects of colleges and universities in Henan Province, China (recipient WC),

\section{Ethics approval and consent to participate}

Informed consent was obtained for study participation from all patients, parent and/or legal guardian for minors and the protocol was approved by the Ethics Committee of the First Affiliated Hospital of Zhengzhou 


\section{Consent for publication}

All authors critically reviewed and approved the final manuscript.

\section{Competing interests}

The authors declare no conflict of interest.

\section{Author contributions}

J.Y. and D.W. designed and directed the study. W. C. and X.L. wrote the manuscript.

R.Z., Z.B., S.Z., L.L., H.X., C.L., X.X., Z.J. and D.W. contributed for the clinical data and patients' treatment. All authors critically reviewed and approved the final manuscript.

\section{Authors information}

The First Affiliated Hospital of Zhengzhou University, Zhengzhou, 450052, Henan, China.

Weijie Cao, Xiaoning Li, Ran Zhang, Zhilei Bian, Suping Zhang, Li Li, Haizhou Xing, Changfeng Liu, Xinsheng Xie, Zhongxing Jiang, Jifeng Yu and Dingming Wan.

Henan International Joint Laboratory of Nuclear Protein Gene Regulation, Henan University College of Medicine, Kaifeng, 475004 Henan, China.

Jifeng Yu

\section{References}

1. Yu J, Jiang PYZ, Sun H, Zhang X, Jiang Z, Li Y, et al. Advances in targeted therapy for acute myeloid leukemia. Biomarker research. 2020;8:17.

2. Copelan EA. Hematopoietic stem-cell transplantation. The New England journal of medicine. 2006;354(17):1813-26.

3. Yang X, Wang J. Precision therapy for acute myeloid leukemia. Journal of hematology \& oncology. 2018;11(1):3.

4. Tsirigotis P, Byrne M, Schmid C, Baron F, Ciceri F, Esteve J, et al. Relapse of AML after hematopoietic stem cell transplantation: methods of monitoring and preventive strategies. A review from the ALWP of the EBMT. Bone marrow transplantation. 2016;51(11):1431-8.

5. Bejanyan N, Weisdorf DJ, Logan BR, Wang HL, Devine SM, de Lima M, et al. Survival of patients with acute myeloid leukemia relapsing after allogeneic hematopoietic cell transplantation: a center for 
international blood and marrow transplant research study. Biology of blood and marrow transplantation : journal of the American Society for Blood and Marrow Transplantation. 2015;21(3):454-9.

6. Abdul Wahid SF, Ismail NA, Mohd-Idris MR, Jamaluddin FW, Tumian N, Sze-Wei EY, et al. Comparison of reduced-intensity and myeloablative conditioning regimens for allogeneic hematopoietic stem cell transplantation in patients with acute myeloid leukemia and acute lymphoblastic leukemia: a metaanalysis. Stem cells and development. 2014;23(21):2535-52.

7. Rubio MT, Savani BN, Labopin M, Piemontese S, Polge E, Ciceri F, et al. Impact of conditioning intensity in T-replete haplo-identical stem cell transplantation for acute leukemia: a report from the acute leukemia working party of the EBMT. Journal of hematology \& oncology. 2016;9:25.

8. Terwijn M, van Putten WL, Kelder A, van der Velden VH, Brooimans RA, Pabst T, et al. High prognostic impact of flow cytometric minimal residual disease detection in acute myeloid leukemia: data from the HOVON/SAKK AML 42A study. Journal of clinical oncology : official journal of the American Society of Clinical Oncology. 2013;31(31):3889-97.

9. Grimm J, Jentzsch M, Bill M, Goldmann K, Schulz J, Niederwieser D, et al. Prognostic impact of the ELN2017 risk classification in patients with AML receiving allogeneic transplantation. Blood advances. 2020;4(16):3864-74.

10. Vicente D, Lamparelli T, Gualandi F, Occhini D, Raiola AM, Ibatici A, et al. Improved outcome in young adults with de novo acute myeloid leukemia in first remission, undergoing an allogeneic bone marrow transplant. Bone marrow transplantation. 2007;40(4):349-54.

11. Saber W, Opie S, Rizzo JD, Zhang MJ, Horowitz MM, Schriber J. Outcomes after matched unrelated donor versus identical sibling hematopoietic cell transplantation in adults with acute myelogenous leukemia. Blood. 2012;119(17):3908-16.

12. Sengsayadeth S, Labopin M, Boumendil A, Finke J, Ganser A, Stelljes M, et al. Transplant Outcomes for Secondary Acute Myeloid Leukemia: Acute Leukemia Working Party of the European Society for Blood and Bone Marrow Transplantation Study. Biology of blood and marrow transplantation : journal of the American Society for Blood and Marrow Transplantation. 2018;24(7):1406-14.

13. Armand P, Gibson CJ, Cutler C, Ho VT, Koreth J, Alyea EP, et al. A disease risk index for patients undergoing allogeneic stem cell transplantation. Blood. 2012;120(4):905-13.

14. Armand P, Kim HT, Logan BR, Wang Z, Alyea EP, Kalaycio ME, et al. Validation and refinement of the Disease Risk Index for allogeneic stem cell transplantation. Blood. 2014;123(23):3664-71.

15. Sorror ML, Maris MB, Storb R, Baron F, Sandmaier BM, Maloney DG, et al. Hematopoietic cell transplantation (HCT)-specific comorbidity index: a new tool for risk assessment before allogeneic HCT. Blood. 2005;106(8):2912-9.

16. Sorror ML, Storb RF, Sandmaier BM, Maziarz RT, Pulsipher MA, Maris MB, et al. Comorbidity-age index: a clinical measure of biologic age before allogeneic hematopoietic cell transplantation. Journal of clinical oncology : official journal of the American Society of Clinical Oncology. 2014;32(29):3249-56.

17. Bejanyan N, Brunstein CG, Cao Q, Lazaryan A, Ustun C, Warlick ED, et al. Predictive value of disease risk comorbidity index for overall survival after allogeneic hematopoietic transplantation. Blood advances. 2019;3(3):230-6. 
18. Walter RB, Gooley TA, Wood BL, Milano F, Fang M, Sorror ML, et al. Impact of pretransplantation minimal residual disease, as detected by multiparametric flow cytometry, on outcome of myeloablative hematopoietic cell transplantation for acute myeloid leukemia. Journal of clinical oncology : official journal of the American Society of Clinical Oncology. 2011;29(9):1190-7.

19. Walter RB, Buckley SA, Pagel JM, Wood BL, Storer BE, Sandmaier BM, et al. Significance of minimal residual disease before myeloablative allogeneic hematopoietic cell transplantation for AML in first and second complete remission. Blood. 2013;122(10):1813-21.

20. Liu J, Ma R, Liu YR, Xu LP, Zhang XH, Chen H, et al. The significance of peri-transplantation minimal residual disease assessed by multiparameter flow cytometry on outcomes for adult AML patients receiving haploidentical allografts. Bone marrow transplantation. 2019;54(4):567-77.

21. Kongtim P, Hasan O, Perez JMR, Varma A, Wang SA, Patel KP, et al. Novel Disease Risk Model for Patients with Acute Myeloid Leukemia Receiving Allogeneic Hematopoietic Cell Transplantation. Biology of blood and marrow transplantation : journal of the American Society for Blood and Marrow Transplantation. 2020;26(1):197-203.

22. Döhner H, Estey E, Grimwade D, Amadori S, Appelbaum FR, Büchner T, et al. Diagnosis and management of AML in adults: 2017 ELN recommendations from an international expert panel. Blood. 2017;129(4):424-47.

23. Schuurhuis GJ, Heuser M, Freeman S, Béné MC, Buccisano F, Cloos J, et al. Minimal/measurable residual disease in AML: a consensus document from the European LeukemiaNet MRD Working Party. Blood. 2018;131(12):1275-91.

24. Przepiorka D, Weisdorf D, Martin P, Klingemann HG, Beatty P, Hows J, et al. 1994 Consensus Conference on Acute GVHD Grading. Bone marrow transplantation. 1995;15(6):825-8.

25. Filipovich AH, Weisdorf D, Pavletic S, Socie G, Wingard JR, Lee SJ, et al. National Institutes of Health consensus development project on criteria for clinical trials in chronic graft-versus-host disease: I. Diagnosis and staging working group report. Biology of blood and marrow transplantation : journal of the American Society for Blood and Marrow Transplantation. 2005;11(12):945-56.

26. Sorror ML, Martin PJ, Storb RF, Bhatia S, Maziarz RT, Pulsipher MA, et al. Pretransplant comorbidities predict severity of acute graft-versus-host disease and subsequent mortality. Blood. 2014;124(2):28795.

27. Sorror ML, Giralt S, Sandmaier BM, De Lima M, Shahjahan M, Maloney DG, et al. Hematopoietic cell transplantation specific comorbidity index as an outcome predictor for patients with acute myeloid leukemia in first remission: combined FHCRC and MDACC experiences. Blood. 2007;110(13):4606-13.

\section{Tables}


Table 1. Patient characteristics

\begin{tabular}{|c|c|c|c|c|c|c|c|}
\hline & \multicolumn{3}{|c|}{ AML-DRG } & \multicolumn{4}{|c|}{ AML-HCT-CR } \\
\hline & Low & Intermediate & High & Low & Intermediate $(\mathrm{n}=25)$ & High & $\begin{array}{l}\text { Very } \\
\text { high }\end{array}$ \\
\hline & $(n=68)$ & $(n=43)$ & $(n=12)$ & $(n=68)$ & & $(n=18)$ & $(n=12)$ \\
\hline $\begin{array}{l}\text { Gender, } \\
\text { female (\%) }\end{array}$ & $\begin{array}{l}28 \\
(41 \%)\end{array}$ & $23(53 \%)$ & $\begin{array}{l}6 \\
(50 \%)\end{array}$ & $\begin{array}{l}28 \\
(41 \%)\end{array}$ & $12(48 \%)$ & $\begin{array}{l}11 \\
(61 \%)\end{array}$ & $\begin{array}{l}6 \\
(50 \%)\end{array}$ \\
\hline $\begin{array}{l}\text { Median age, } \\
\text { years }\end{array}$ & $\begin{array}{l}32(12- \\
62)\end{array}$ & $30(16-56)$ & $\begin{array}{l}28(15- \\
45)\end{array}$ & $\begin{array}{l}32(12- \\
62)\end{array}$ & $27(16-50)$ & $\begin{array}{l}32 \\
(16- \\
56)\end{array}$ & $\begin{array}{l}28(15- \\
51)\end{array}$ \\
\hline $\begin{array}{l}\text { White blood } \\
\text { cells at } \\
\text { diagnosis, }\end{array}$ & $\begin{array}{l}23(1- \\
259)\end{array}$ & $27(1-360)$ & $\begin{array}{l}27(5- \\
203)\end{array}$ & $\begin{array}{l}23(1- \\
259)\end{array}$ & $18(1-360)$ & $\begin{array}{l}32(2- \\
333)\end{array}$ & $\begin{array}{l}28(5- \\
203)\end{array}$ \\
\hline \multicolumn{8}{|l|}{$\times 10^{9}$ per $L$} \\
\hline \multicolumn{8}{|l|}{ AML type (\%) } \\
\hline De novo & $\begin{array}{l}68 \\
(100 \%)\end{array}$ & $40(93 \%)$ & $\begin{array}{l}9 \\
(75 \%)\end{array}$ & $\begin{array}{l}68 \\
(100 \%)\end{array}$ & $24(96 \%)$ & $\begin{array}{l}16 \\
(89 \%)\end{array}$ & $\begin{array}{l}9 \\
(75 \%)\end{array}$ \\
\hline Secondary & $0(0 \%)$ & $3(7 \%)$ & $\begin{array}{l}3 \\
(25 \%)\end{array}$ & $0(0 \%)$ & $1(4 \%)$ & $\begin{array}{l}2 \\
(11 \%)\end{array}$ & $\begin{array}{l}3 \\
(25 \%)\end{array}$ \\
\hline \multicolumn{8}{|l|}{$\begin{array}{l}\text { ELN2017 } \\
\text { genetic risk } \\
\text { group }\end{array}$} \\
\hline Favorable & $\begin{array}{l}12 \\
(18 \%)\end{array}$ & $2(5 \%)$ & $0(0 \%)$ & $\begin{array}{l}12 \\
(18 \%)\end{array}$ & $0(0 \%)$ & $\begin{array}{l}2 \\
(11 \%)\end{array}$ & $0(0 \%)$ \\
\hline Intermediate & $\begin{array}{l}45 \\
(66 \%)\end{array}$ & $12(28 \%)$ & $1(8 \%)$ & $\begin{array}{l}45 \\
(66 \%)\end{array}$ & $1(4 \%)$ & $\begin{array}{l}11 \\
(61 \%)\end{array}$ & $1(8 \%)$ \\
\hline Adverse & $\begin{array}{l}11 \\
(16 \%)\end{array}$ & $29(67 \%)$ & $\begin{array}{l}11 \\
(92 \%)\end{array}$ & $\begin{array}{l}11 \\
(16 \%)\end{array}$ & $24(96 \%)$ & $\begin{array}{l}5 \\
(28 \%)\end{array}$ & $\begin{array}{l}11 \\
(92 \%)\end{array}$ \\
\hline \multicolumn{8}{|l|}{$\begin{array}{l}\text { MRD status } \\
\text { at transplant }\end{array}$} \\
\hline $\begin{array}{l}\text { CR with MRD } \\
\text { negative }\end{array}$ & $\begin{array}{l}23 \\
(34 \%)\end{array}$ & $1(2 \%)$ & $0(0 \%)$ & $\begin{array}{l}23 \\
(34 \%)\end{array}$ & $0(0 \%)$ & $1(6 \%)$ & $0(0 \%)$ \\
\hline $\begin{array}{l}\text { CR with MRD } \\
\text { positive }\end{array}$ & $\begin{array}{l}45 \\
(66 \%)\end{array}$ & $33(77 \%)$ & $1(8 \%)$ & $\begin{array}{l}45 \\
(66 \%)\end{array}$ & 25 (100\%) & $\begin{array}{l}8 \\
(44 \%)\end{array}$ & $0(0 \%)$ \\
\hline $\begin{array}{l}\text { Active } \\
\text { disease }\end{array}$ & $0(0 \%)$ & $9(21 \%)$ & $\begin{array}{l}11 \\
(92 \%)\end{array}$ & $0(0 \%)$ & $0(0 \% 0$ & $9(5 \%)$ & $\begin{array}{l}12 \\
(100 \%)\end{array}$ \\
\hline $\begin{array}{l}\text { Median HCT- } \\
\mathrm{Cl}\end{array}$ & $1(0-2)$ & $1(0-4)$ & $1(0-1)$ & $1(0-2)$ & $1(0-1)$ & $1(1-4)$ & $1(0-3)$ \\
\hline $\begin{array}{l}\text { Median HCT- } \\
\text { Cl/Age }\end{array}$ & $1(0-3)$ & $1(0-5)$ & $1(0-2)$ & $1(0-3)$ & $1(0-2)$ & $1(1-5)$ & $1(0-4)$ \\
\hline
\end{tabular}




\begin{tabular}{|c|c|c|c|c|c|c|c|}
\hline \multicolumn{8}{|l|}{ DRI (\%) } \\
\hline Low & $4(6 \%)$ & $0(0 \%)$ & $0(0 \%)$ & $4(6 \%)$ & $0(0 \%)$ & $0(0 \%)$ & $0(0 \%)$ \\
\hline Intermediate & $\begin{array}{l}58 \\
(85 \%)\end{array}$ & 21 (49\%) & $1(8 \%)$ & $\begin{array}{l}58 \\
(85 \%)\end{array}$ & 12 (48\%) & $\begin{array}{l}9 \\
(50 \%)\end{array}$ & $1(8 \%)$ \\
\hline High & $6(9 \%)$ & $22(51 \%)$ & $\begin{array}{l}9 \\
(75 \%)\end{array}$ & $6(9 \%)$ & 13 (52\%) & $\begin{array}{l}9 \\
(50 \%)\end{array}$ & $\begin{array}{l}9 \\
(75 \%)\end{array}$ \\
\hline Very high & $0(0 \%)$ & $0(0 \%)$ & $\begin{array}{l}2 \\
(17 \%)\end{array}$ & $0(0 \%)$ & $0(0 \%)$ & $0(0 \%)$ & $\begin{array}{l}2 \\
(17 \%)\end{array}$ \\
\hline \multicolumn{8}{|l|}{$\begin{array}{l}\text { Conditioning } \\
\text { type (\%) }\end{array}$} \\
\hline $\begin{array}{l}\text { Busulfan- } \\
\text { based }\end{array}$ & $\begin{array}{l}66 \\
(97 \%)\end{array}$ & 41 (95\%) & $\begin{array}{l}12 \\
(100 \%)\end{array}$ & $\begin{array}{l}66 \\
(97 \%)\end{array}$ & 25 (100\%) & $\begin{array}{l}16 \\
(89 \%)\end{array}$ & $\begin{array}{l}12 \\
(100 \%)\end{array}$ \\
\hline TBI-based & $2(3 \%)$ & $2(5 \%)$ & $0(0 \%)$ & $2(3 \%)$ & $0(0 \%)$ & $\begin{array}{l}2 \\
(11 \%)\end{array}$ & $0(0 \%)$ \\
\hline
\end{tabular}

Donor type

(\%)

\begin{tabular}{|c|c|c|c|c|c|c|c|}
\hline $\begin{array}{l}\text { HLA- } \\
\text { matched } \\
\text { sibling donor }\end{array}$ & $\begin{array}{l}37 \\
(54 \%)\end{array}$ & $21(49 \%)$ & $\begin{array}{l}7 \\
(58 \%)\end{array}$ & $\begin{array}{l}37 \\
(54 \%)\end{array}$ & $15(60 \%)$ & $\begin{array}{l}5 \\
(28 \% 0\end{array}$ & $\begin{array}{l}8 \\
(67 \%)\end{array}$ \\
\hline $\begin{array}{l}\quad \text { HLA- } \\
\text { matched } \\
\text { unrelated } \\
\text { donor }\end{array}$ & $\begin{array}{l}14 \\
(21 \%)\end{array}$ & $5(12 \%)$ & $0(0 \%)$ & $\begin{array}{l}14 \\
(21 \%)\end{array}$ & $5(20 \%)$ & $0(0 \%)$ & $0(0 \%)$ \\
\hline $\begin{array}{l}\text { HLA- } \\
\text { haploidentical } \\
\text { donor }\end{array}$ & $\begin{array}{l}17 \\
(25 \%)\end{array}$ & 17 (39\%) & $\begin{array}{l}5 \\
(42 \%)\end{array}$ & $\begin{array}{l}17 \\
(25 \%)\end{array}$ & $5(20 \%)$ & $\begin{array}{l}13 \\
(72 \%)\end{array}$ & $\begin{array}{l}4 \\
(33 \%)\end{array}$ \\
\hline \multicolumn{8}{|l|}{$\begin{array}{l}\text { Stem cell } \\
\text { source (\%) }\end{array}$} \\
\hline PBSC & $\begin{array}{l}64 \\
(94 \%)\end{array}$ & 39 (91\%) & $\begin{array}{l}12 \\
(100 \%)\end{array}$ & $\begin{array}{l}64 \\
(94 \%)\end{array}$ & $24(96 \%)$ & $\begin{array}{l}15 \\
(83 \%)\end{array}$ & $\begin{array}{l}12 \\
(100 \%)\end{array}$ \\
\hline $\begin{array}{l}\text { PBSC + } \\
\text { BMSC }\end{array}$ & $4(6 \%)$ & $4(9 \%)$ & $0(0 \%)$ & $4(6 \%)$ & $1(4 \%)$ & $\begin{array}{l}3 \\
(17 \%)\end{array}$ & $0(0 \%)$ \\
\hline
\end{tabular}

Abbreviations: AML-acute myeloid leukemia; CR-complete remission; $\mathrm{HC}-\mathrm{Cl} /$ Age-comorbidity-age index; DRI-disease risk index; BMSC-bone marrow stem cell; PBSC-peripheral blood stem cell; TBI: total body irradiation 
Table 2. Outcomes of AHCT according to the AML-DRG and AML-HCT-CR models

\begin{tabular}{|c|c|c|c|c|c|c|}
\hline & $\begin{array}{l}\text { 3-year } \\
\text { OS, }\end{array}$ & $\begin{array}{l}\text { 3-year } \\
\text { PFS, }\end{array}$ & $\begin{array}{l}\text { 3-year } \\
\text { relapse, }\end{array}$ & $\begin{array}{l}\text { 3-year } \\
\text { NRM, }\end{array}$ & $\begin{array}{l}\text { Grade】 } \square \text { aGVHD, } \\
\%\end{array}$ & $\begin{array}{l}\text { ALL- } \\
\text { grade } \\
\text { cGVHD, } \\
\%\end{array}$ \\
\hline & $\begin{array}{l}\% \\
(95 \% \mathrm{Cl})\end{array}$ & $\begin{array}{l}\% \\
(95 \% \mathrm{Cl})\end{array}$ & $\begin{array}{l}\% \\
(95 \% \mathrm{Cl})\end{array}$ & $\begin{array}{l}\% \\
(95 \% \mathrm{Cl})\end{array}$ & $(95 \% \mathrm{Cl})$ & $(95 \% \mathrm{Cl})$ \\
\hline AML-DRG & $p<0.001$ & $p<0.001$ & $P=0.002$ & $P=0.314$ & $P=0.980$ & $P=0.211$ \\
\hline $\operatorname{Low}(n=68)$ & $\begin{array}{l}65.4 \\
(54.9- \\
78.0)\end{array}$ & $\begin{array}{l}64.0 \\
(53.5- \\
76.7)\end{array}$ & $\begin{array}{l}13.6(8.7- \\
18.5)\end{array}$ & $\begin{array}{l}22.3 \\
(17.0- \\
27.7)\end{array}$ & $19.1(16.6-21.7)$ & $\begin{array}{l}31.3 \\
(25.6- \\
37.0)\end{array}$ \\
\hline Intermediate $(n=43)$ & $\begin{array}{l}34.9 \\
(23.2- \\
52.5)\end{array}$ & $\begin{array}{l}34.9 \\
(23.2- \\
52.5)\end{array}$ & $\begin{array}{l}30.2 \\
(22.3- \\
38.2)\end{array}$ & $\begin{array}{l}34.9 \\
(26.8- \\
43.0)\end{array}$ & $18.6(11.3-25.9)$ & $\begin{array}{l}20.9 \\
(13.4- \\
28.4)\end{array}$ \\
\hline $\operatorname{High}(\mathrm{n}=12)$ & $\begin{array}{l}8.3(1.3- \\
54.4)\end{array}$ & $\begin{array}{l}8.3(1.3- \\
54.4)\end{array}$ & $\begin{array}{l}50(27.6- \\
72.4)\end{array}$ & $\begin{array}{l}41.7 \\
(19.0- \\
64.4)\end{array}$ & $16.7(0-36.0)$ & $\begin{array}{l}8.3(0- \\
25.8)\end{array}$ \\
\hline AML-HCT-CR & $p<0.001$ & $p<0.001$ & $P=0.005$ & $P=0.095$ & $P=0.610$ & $P=0.252$ \\
\hline $\operatorname{Low}(n=68)$ & $\begin{array}{l}65.4 \\
(54.9- \\
78.0)\end{array}$ & $\begin{array}{l}64.0 \\
(53.5- \\
76.7)\end{array}$ & $\begin{array}{l}13.6(8.7- \\
18.5)\end{array}$ & $\begin{array}{l}22.3 \\
(17.0- \\
27.7)\end{array}$ & $19.1(13.9-24.3)$ & $\begin{array}{l}31.3 \\
(25.6- \\
37.0)\end{array}$ \\
\hline Intermediate $(\mathrm{n}=25)$ & $\begin{array}{l}52.0 \\
(35.7- \\
75.8)\end{array}$ & $\begin{array}{l}52.0 \\
(35.7- \\
75.8)\end{array}$ & $\begin{array}{l}24.0 \\
(12.4- \\
35.6)\end{array}$ & $\begin{array}{l}24.0 \\
(12.4- \\
35.6)\end{array}$ & $12.0(1.9-22.1)$ & $\begin{array}{l}28.0 \\
(16.1- \\
39.9)\end{array}$ \\
\hline $\operatorname{High}(\mathrm{n}=18)$ & $\begin{array}{l}11.1(3.0- \\
41.0)\end{array}$ & $\begin{array}{l}11.1(3.0- \\
41.0)\end{array}$ & $\begin{array}{l}44.4 \\
(28.3- \\
60.6)\end{array}$ & $\begin{array}{l}44.4 \\
(28.2- \\
60.7)\end{array}$ & $27.8(12.6-43.0)$ & $\begin{array}{l}11.1(0- \\
24.1)\end{array}$ \\
\hline Very high $(n=12)$ & $\begin{array}{l}8.3(1.3- \\
54.4)\end{array}$ & $\begin{array}{l}8.3(1.3- \\
54.4)\end{array}$ & $\begin{array}{l}41.7 \\
(19.7- \\
63.6)\end{array}$ & $\begin{array}{l}50.0 \\
(27.3- \\
72.7)\end{array}$ & $16.7(0.0-36.2)$ & $\begin{array}{l}8.3(0- \\
26.5)\end{array}$ \\
\hline
\end{tabular}

Abbreviations: OS-overall survival; PFS-progression-free survival; NRM-non-relapse mortality; aGVHDacute GVHD; cGVHD-chronic GVHD 
Table 3. Univariable analysis evaluating the impact of the HCT-CR model on OS and PFS

\begin{tabular}{|c|c|c|c|}
\hline Univariable analysis for OS & HR & $95 \% \mathrm{Cl}$ & $P$ value \\
\hline \multicolumn{4}{|l|}{ AML-DRG } \\
\hline Low & Reference & & \\
\hline Intermediate & 2.29 & $1.33-3.93$ & 0.003 \\
\hline High & 5.14 & $2.50-10.57$ & $<0.001$ \\
\hline \multicolumn{4}{|l|}{ AML-HCT-CR } \\
\hline Low & Reference & & \\
\hline Intermediate & 1.37 & $0.69-2.72$ & 0.368 \\
\hline High & 4.43 & $2.32-8.49$ & $<0.001$ \\
\hline Very high & 5.82 & $2.81-12.04$ & $<0.001$ \\
\hline \multicolumn{4}{|l|}{ Univariable analysis for PFS } \\
\hline \multicolumn{4}{|l|}{ AML-DRG } \\
\hline Low & Reference & & \\
\hline Intermediate & 2.34 & $1.37-4.01$ & 0.002 \\
\hline High & 5.57 & $2.71-11.48$ & $<0.001$ \\
\hline \multicolumn{4}{|l|}{ AML-HCT-CR } \\
\hline Low & Reference & & \\
\hline Intermediate & 1.37 & $0.69-2.72$ & 0.368 \\
\hline High & 4.95 & $2.59-9.45$ & $<0.001$ \\
\hline Very high & 6.15 & $2.96-12.73$ & $<0.001$ \\
\hline
\end{tabular}

Abbreviations: HR-hazard ratio; Cl-confidence interval; OS-overall survival; PFS-progression-free survival. 
Table 4. Multivariable analysis for OS

\begin{tabular}{|c|c|c|c|c|c|c|}
\hline \multirow[b]{2}{*}{ Variable } & \multicolumn{3}{|l|}{ AML-DRG } & \multicolumn{3}{|c|}{ AML-HCT-CR } \\
\hline & HR & $95 \% \mathrm{Cl}$ & $\begin{array}{l}P \\
\text { value }\end{array}$ & HR & $95 \% \mathrm{Cl}$ & $\begin{array}{l}P \\
\text { value }\end{array}$ \\
\hline AML-DRG or AML-HCT-CR & & & $<0.001$ & & & $<0.001$ \\
\hline Low & Reference & & & Refe & & \\
\hline Intermediate & 2.26 & $\begin{array}{l}1.30- \\
3.93\end{array}$ & 0.004 & 1.62 & $\begin{array}{l}0.81- \\
3.28\end{array}$ & 0.172 \\
\hline High & 4.52 & $\begin{array}{l}2.01- \\
9.72\end{array}$ & $<0.001$ & 3 & $\begin{array}{l}1.51- \\
5.94\end{array}$ & 0.002 \\
\hline Very high & & & & 5.95 & $\begin{array}{l}2.78- \\
12.73\end{array}$ & $<0.001$ \\
\hline Age (continuous variable) & 1.03 & $\begin{array}{l}1.01- \\
1.06\end{array}$ & 0.02 & 1.03 & $\begin{array}{l}1.00- \\
1.06\end{array}$ & 0.024 \\
\hline Sex (male vs. female) & 1.1 & $\begin{array}{l}0.67- \\
1.83\end{array}$ & 0.702 & 1.15 & $\begin{array}{l}0.68- \\
1.94\end{array}$ & 0.589 \\
\hline $\begin{array}{l}\text { Conditioning type (Bu-vs. TBI- } \\
\text { based) }\end{array}$ & 1.32 & $\begin{array}{l}0.40- \\
4.35\end{array}$ & 0.647 & 1.16 & $\begin{array}{l}0.35- \\
3.90\end{array}$ & 0.81 \\
\hline PBSC vs. BMSC+PBSC & 0.94 & $\begin{array}{l}0.38- \\
2.32\end{array}$ & 0.888 & 0.91 & $\begin{array}{l}0.36- \\
2.27\end{array}$ & 0.908 \\
\hline
\end{tabular}

Transplant modality

\begin{tabular}{|c|c|c|c|c|c|c|}
\hline HLA-matched sibling donor & Reference & & & Refer & & \\
\hline HLA-matched unrelated donor & 0.46 & $\begin{array}{l}0.16- \\
1.35\end{array}$ & 0.158 & 0.63 & $\begin{array}{l}0.18- \\
1.54\end{array}$ & 0.241 \\
\hline HLA-haploidentical donor & 2.21 & $\begin{array}{l}1.24- \\
3.96\end{array}$ & 0.007 & 2.1 & $\begin{array}{l}1.15- \\
3.84\end{array}$ & 0.016 \\
\hline
\end{tabular}

Abbreviations: HR-hazard ratio; Cl-confidence interval; BMSC-bone marrow stem cell; PBSC-peripheral blood stem cell; Bu: Busulfan; TBl: total body irradiation

\section{Figures}


Figure 1A

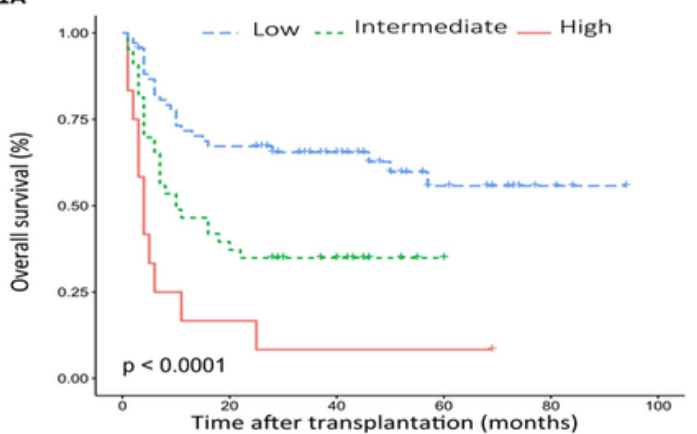

Number at risk

\begin{tabular}{|c|c|c|c|c|}
\hline High & 2 & 1 & 1 & o \\
\hline diate & 17 & 11 & 1 & o \\
\hline Low & 45 & 29 & 12 & 4 \\
\hline
\end{tabular}
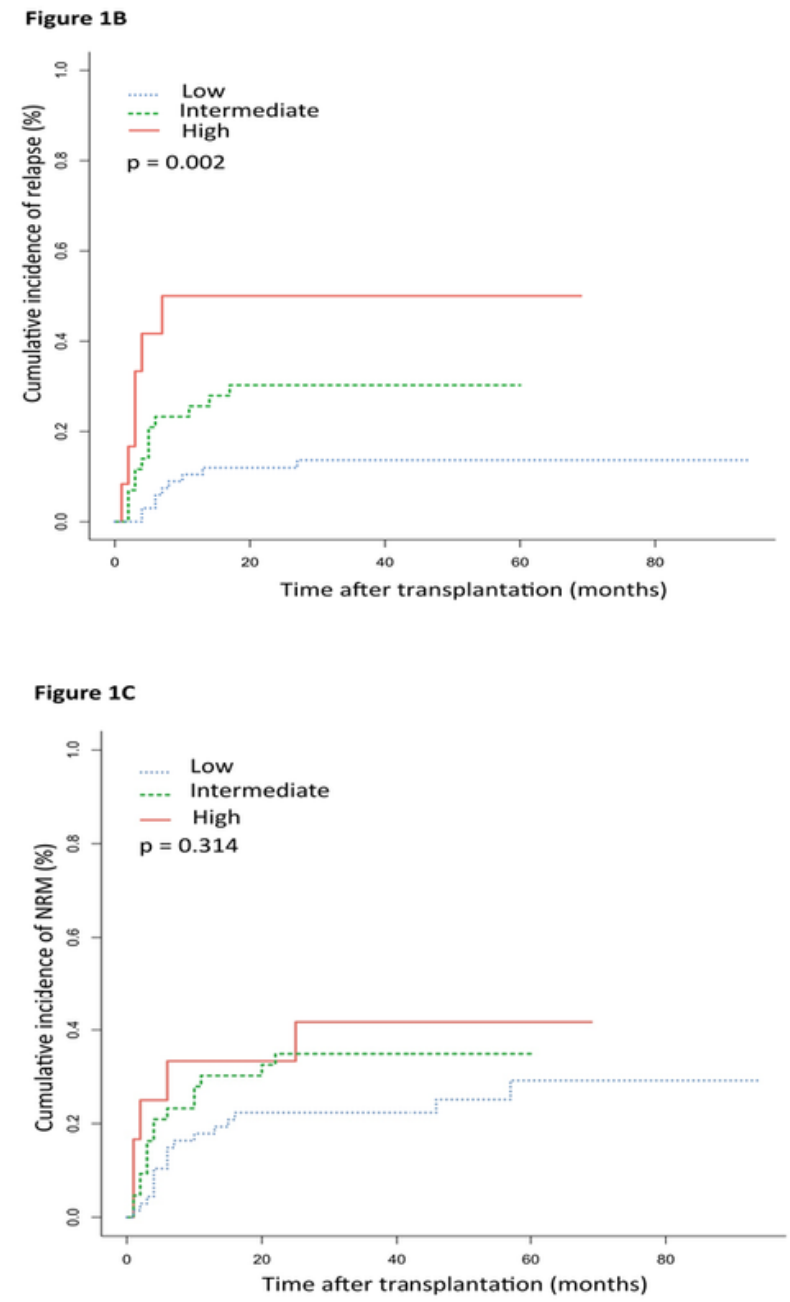

Figure 1

1A. Overall survival of in patients with low, intermediate and high risk groups with AML-DRG B. Cumulative incidence of relapse in patients with low, intermediate and high risk groups C. Cumulative incidence of NRM in patients with low, intermediate and high risk groups 

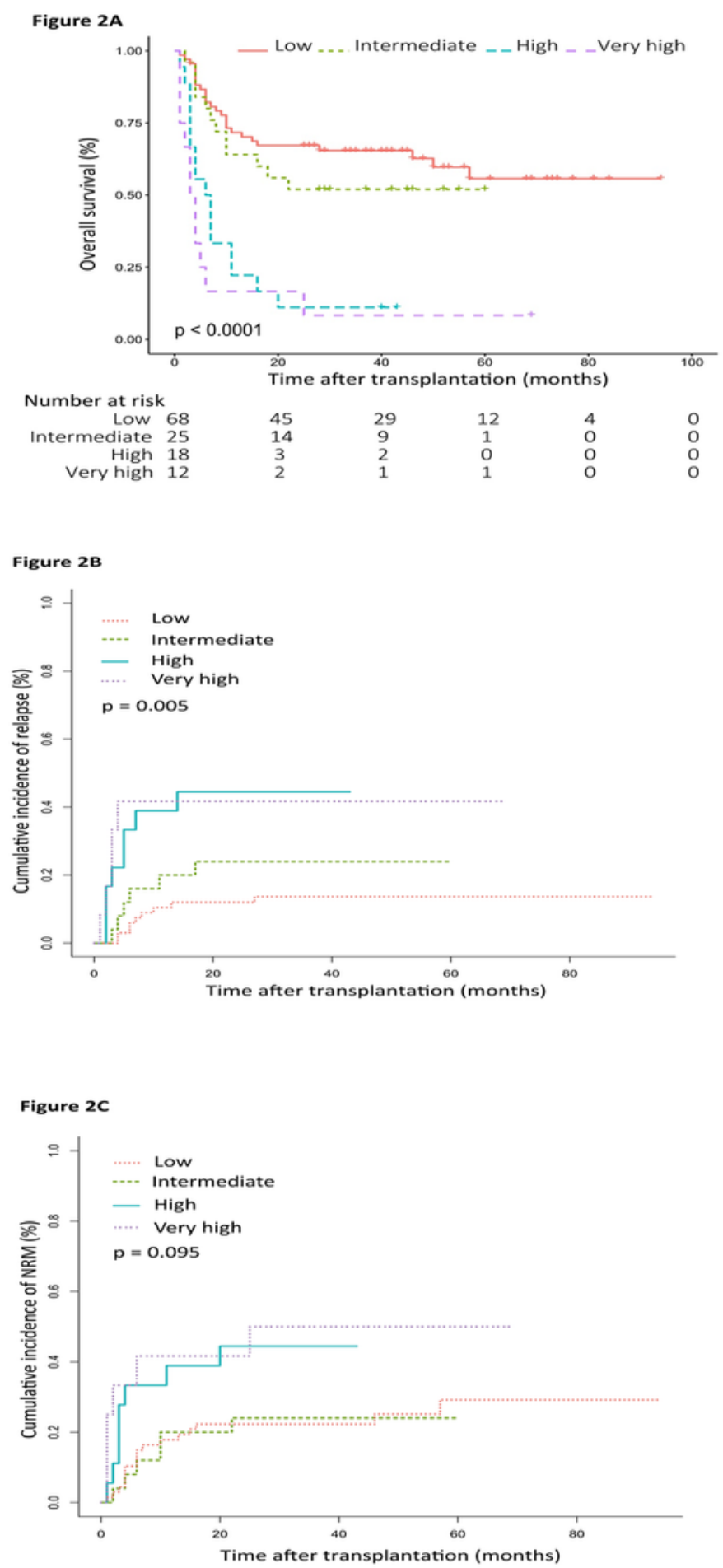

\section{Figure 2}

A. Overall survival of in patients with low, intermediate, high and very high risk groups with AML-HCT-CR B. Cumulative incidence of relapse in patients with low, intermediate, high and very high risk groups. C. Cumulative incidence of NRM in patients with low, intermediate, high and very high risk groups 